\title{
Villiers $v$ Villiers: the end of the line? Case study of the Supreme Court decision reported at [2020] UKSC 30
}

\author{
Mrs Justice Keegan
}

Senior Family Judge of the High Court of Northern Ireland

\section{INTRODUCTION}

$\mathrm{T}$ his divorce case has attracted much attention not least due to the fact that it has been before the Supreme Court after numerous interlocutory hearings before the courts of England and Wales. The split decision given by the Supreme Court has engendered much commentary about the potential for divorce tourism, particularly in relation to maintenance. The core characteristic of the case was that one party wished to litigate for maintenance in England and one in Scotland. Although close geographically, each of these intra United Kingdom (UK) jurisdictions applies different legal principles when it comes to maintenance. The English courts have traditionally taken a more liberal approach to maintenance, whereas in Scotland maintenance is usually capped for a period of time. Hence, the suggestion of divorce/ maintenance tourism.

This case relates to a part of the Matrimonial Causes Act 1973 which is not widely used, namely section 27. The corollary in Northern Irish legislation is article 29 of the Matrimonial Causes (Northern Ireland) Order 1978. Both provisions are similar and allow for financial provision in cases of neglect by a party to a marriage to maintain the other party or child of the family. Article 29(1) reads:

29.-(1) Either party to a marriage may apply to the court for an order under this Article on the ground that the other party to the marriage ('the respondent')-

(a) has failed to provide reasonable maintenance for the applicant, or

(b)has failed to provide, or to make a proper contribution towards, reasonable maintenance for any child of the family.

I do not know of any reported cases in Northern Ireland in relation to article 29. Whilst there have been a few applications over the years, they have ultimately settled and not involved protracted litigation. Notwithstanding the limited use of this provision, the Supreme Court case brought into focus issues of jurisdiction of considerable interest in relation to disputes in divorce intra UK and the application of European Union law in this area. 
That is because the case was essentially about the interpretation and effect of schedule 6 to the Civil Jurisdiction and Judgments (Maintenance) Regulations 2011 and the interpretation and effect of Council Regulation EC No 42009 (the Maintenance Regulation) on jurisdiction, applicable law, recognition and enforcement of decisions in co-operation in matters relating to maintenance obligations. Of course, with the Withdrawal Act 2020 following Brexit the issue of the applicability of the Maintenance Regulation fades away. So, the initial flurry about this case has passed, and in real terms it is likely to have limited application going forward.

\section{THE BACKGROUND}

The case involved parties who were married in 1994 in England but who lived in Scotland between 1995 and 2012. They separated in 2012. The wife returned to England in 2012 and has lived there since. On 13 January 2015 she issued her application under section 27 in England for an order requiring the husband to make maintenance payments. The wife had issued a divorce petition in England in July 2013 which included a prayer for financial orders. The husband issued a writ for divorce in Scotland in October 2014 which included relief in the form of an order to dissolve the marriage but no prayer in relation to financial matters.

As the Supreme Court pointed out, the effect of the relevant statutory provision (schedule 1, paragraph 8, Domicile and Matrimonial Proceedings Act 1973) was that the application for divorce had to be assigned to the court in Scotland, since the parties had last lived there together. The wife accepted this, and on 13 January 2015 she consented to an order dismissing her petition in England, which order was made on 16 January 2015. Therefore, the husband's divorce could proceed in Scotland.

A section 27 application is not tied to the grant of divorce, and it can be sought in separate proceedings. Therefore, the wife, notwithstanding the withdrawal of the divorce petition, issued the application for maintenance on the same day that she withdrew her petition. The issue was whether or not, given the Scottish petition, the application should be either stayed or dismissed.

\section{THE PROGRESS OF COURT PROCEEDINGS}

The application was heard before Mrs Justice Parker in the High Court. In her decision, which is reported at [2016] EWHC 668, Parker J rejected the challenge to the jurisdiction of the English court and made an order for interim maintenance. This was an order in favour of the 
wife for interim maintenance in the sum of $£ 2500$ per month backdated to the date of the issue of the application, namely 15 January 2015, payable monthly in advance, with arrears to be paid within six weeks.

The husband appealed to the Court of Appeal. His appeal was dismissed by the court in a judgment reported as [2018] EWCA Civ 1120. Thereafter, the Supreme Court granted leave to appeal and essentially found in favour, again, of allowing the section 27 application to be heard in England and Wales.

\section{THE OPINIONS IN THE SUPREME COURT}

The Supreme Court was split in this case, with the majority opinion given by Lord Sales with whom Lord Kerr agreed and Lady Black, who gave a separate concurring judgment. In the minority were Lord Wilson with whom Lady Hale agreed.

The majority held that, first, schedule 6 of the Civil Jurisdiction and Judgments (Maintenance) Regulations 2011 imported in modified form the jurisdiction and other legal rules in the Maintenance Regulation to intra UK jurisdictional disputes.

Second, there was no scope for the operation of a forum non conveniens discretion in the context of the legislative scheme of schedule 6; it was not preserved by section 49 of the Civil Jurisdiction and Judgments Act 1982. Therefore, the English courts had no discretion to stay the section 27 application on the ground of forum non conveniens.

And, finally, the wife's application could not be stayed under article 13 of the Maintenance Regulation (as imported by schedule 6) as a related action. The fundamental object of the mandatory rule of jurisdiction in article 3 of the Maintenance Regulation was to afford special protection for a maintenance creditor by giving her the right to choose the jurisdiction in which to bring a claim for maintenance. Interpreting article 13 of the Maintenance Regulation in the light of that object, related actions in article 13 referred primarily to maintenance claims of the kind to which the Maintenance Regulation applied, and any extension of the concept of related actions beyond this was confined to cases where there was a risk of irreconcilable judgments. In the present case there was no relevant connection between the wife's English maintenance claim under section 27 of the Matrimonial Causes Act 1973 and the husband's Scottish proceedings concerning marital status, and thus no risk of irreconcilable judgments. Therefore, the two sets of proceedings were not related actions for the purposes of article 13 of the Maintenance Regulation, as applied by schedule 6 and, 
accordingly, the court had no jurisdiction to stay the wife's application for maintenance.

The concurring judgment of Lady Black agrees with the majority. However, Lady Black clearly had some struggles with the outworking of the majority decision given that she describes the related action point as 'extremely difficult'. Interestingly, Lady Black says this:

The natural response of a family lawyer might be to say that obviously one court should resolve all the financial issues that arise upon the ending of a marriage. Indeed, an initial response might be to go further and say that one court should resolve all the issues, of whatever sort, arising upon the ending of a marriage. Further thought would remind the family lawyer that that sort of consolidation is by no means universal, however. Two examples will demonstrate the point. First, jurisdiction in relation to parental responsibility issues is often dictated by the habitual residence of the child (see domestic law and the Brussels II Revised Regulation (Council Regulation (EC) No $2201 / 2003)$ ). Secondly, financial relief can be available in the courts of England and Wales, following the granting of an overseas divorce, under the Matrimonial and Family Proceedings Act 1984, including in situations where there has already been an order elsewhere for a payment, or transfer of property, to be made in favour of the applicant or a child of the family. Nevertheless, the idea of two courts within the United Kingdom both making orders which will regulate the finances of the parties to a marriage following divorce is not very palatable. And yet that is what the position might be if, as the Court of Appeal decided in a very clearly reasoned judgment, article 13 does not permit the court to intervene. [79]

It is Lord Wilson, with whom Lady Hale agreed, who provides a robust dissent. In this Lord Wilson has a clear eye on result. In particular, having analysed the interplay between domestic law and European law, he says this:

The Maintenance Regulation did not change the rules which required or permitted the court of a member state to stay proceedings in respect of which jurisdiction had been conferred on it in favour of the court of another member state. For articles 27 and 28 of the Judgments Regulation were repeated, word for word, in articles 12 and 13 of the Maintenance Regulation. Article 12, entitled 'Lis pendens', provides:

' 1 . Where proceedings involving the same cause of action and between the same parties are brought in the courts of different member states, any court other than the court first seised shall of its own motion stay its proceedings until such time as the jurisdiction of the court first seised is established.

2. Where the jurisdiction of the court first seised is established, any court other than the court first seised shall decline jurisdiction in favour of that court.' [116] 
Lord Wilson highlights that the Article 13 provision entitled 'related actions' is of central importance to the resolution of this appeal.

In looking at article 13 of the Maintenance Regulation, Lord Wilson maintains that it must be construed in its context, adjacent to article 12 . He also refers to article 13(3) which defines the circumstances in which actions are deemed to be related and says:

It is probably intended to provide an exclusive definition of such circumstances. These are that the actions 'are so closely connected that it is expedient to hear and determine them together to avoid the risk of irreconcilable judgments.' But actions in different member states, as also in different parts of a member state, cannot be heard and determined together. Paragraph (3) must mean that it is expedient to hear and determine together the issues raised in the two actions. [150] (original emphasis)

Lord Wilson asks:

Did the majority check its construction of article 13 in the light of its adverse consequences?

His answer is this:

When lawyers conclude that the construction of an instrument is clear, they will not shrink from their conclusion by reference to its adverse consequences. If, however, their provisional conclusion has adverse consequences, they will check it before making it their concluded view. There will be two adverse consequences of today's decision, one expressly noticed only by Lord Sales, and the other only by Lady Black. The first will be the untrammelled licence given to a wife to go forumshopping, in other words to put her husband at an initial disadvantage unrelated to the merits of her case. Having observed that in the $N$ case the judge considered that the wife had engaged in illegitimate forumshopping, Lord Sales comments in para 56 above that she had been entitled to choose the forum for her claim by reference to tactical reasons and that, under the Maintenance Regulation, there had been nothing illegitimate in her doing so. The second will be the inability of a court in one part of the UK to decline to determine a wife's maintenance claim even when a court in another part alone has power to determine a claim by one spouse or the other for transfer of property or for some other adjustment (such as would, for example, disentangle them from joint ownership of property) or for a pension sharing order. As Lady Black says in para 79 above, the prospect is 'not very palatable.' So the final question can be refined: did the adverse consequences of today's decision oblige the majority to undertake a rigorous examination of its provisional conclusion about the meaning of article 13 and, if so and in the light of all the questions posed above, can its provisional conclusion have received rigorous examination? [180] 


\section{THE NEXT CHAPTER}

This case returned to the Family Division of the High Court to consider the section 27 application on its merits, jurisdiction having been established by virtue of the Supreme Court decision. Mr Justice Mostyn decided the case, which is reported at [2021] EWFC 23. In this ruling Mostyn $\mathrm{J}$ examines the history of the case before he turns to the progress of the maintenance application. Quite starkly, he makes the point that under the interim maintenance order made by Parker $\mathrm{J}$ not one penny has been paid.

Mostyn $\mathrm{J}$ also refers to the law in relation to section 27 (our article 29) as the 'condition precedent' in section 1A. He points out that the court has to be satisfied as a condition precedent to make an award of maintenance that the other party to the marriage has failed to provide reasonable maintenance for the applicant. In this context Mostyn J says:

Plainly, the requirement to make this preliminary factual determination must be interpreted purposely and not literally. Plainly, the condition precedent would not be satisfied, say, on proof of the failure to have provided reasonable maintenance for a short period 10 years earlier. It must mean in the period immediately prior to the application the respondent has failed to provide reasonable maintenance for the applicant. That period might be quite long, and the failure may be intermittent, but it must proximate to the application. [128]

Mostyn $\mathrm{J}$ also refers to the fact that there is no authority on the point although it is referenced at Jackson's Matrimonial Finance. ${ }^{1}$ Therefore, he reached the conclusion on the facts that the condition precedent was not satisfied in the case, and he maintained that the logic of this must mean that the order made should be discharged. In the alternative he said that, if he was wrong in his assessment of the condition precedent, the only question is whether the husband, in circumstances where he is now receiving about $£ 28,000$ a year in net income from his two funds by way of discretionary trust, should be maintaining the wife. In this hypothetical scenario, the judge said that the husband ought to pay $£ 10,000$ per annum in maintenance to the wife. Also, in finalising this case, the judge said that once the parties are divorced the court in Scotland should deal with all financial questions between the husband and the wife which would include exercising powers not available to the English court including pension sharing. Therefore, the duration of any maintenance order, if there were one, would only be until the Divorce Court in Scotland dealt with the matter. 
The judge's final comments are these:

Finally, I cannot forebear from observing that had the husband not chosen to challenge the jurisdiction of this court to hear the wife's Section 27 application of 13 January 2015 then it would have been heard on its merits in 2015. I am certain that the same result would have been reached as I have reached in this judgment and that the application would have been dismissed. That would have saved the parties the better part of 6 years of stressful, contentious, ruinously expensive and psychologically damaging litigation warfare. There would have been a divorce long ago in Scotland. Years ago the Sheriff Court at Dumbarton would have finally resolved all financial questions between the parties. I am not blaming the husband for the course that he took; after all, he came within one vote of victory in the Supreme Court. With the benefit of 20/20 hindsight I can, however, lament his decision. [145]

\section{CONCLUSION}

It remains to be seen whether the judgment of Mr Justice Mostyn dealing with the section 27 application will be appealed. However, it is clear that the jurisdictional issue which was decided by the majority in the Supreme Court will have limited application going forward due to the revocation of the Maintenance Regulation. That said, the law as discussed by Mostyn $J$ in relation to how section 27 applications are advanced is of interest. This may form a subject matter of continued debate, but in any event this mechanism is very rarely utilised in this jurisdiction. The moral of this tale is perhaps found in the fact that the jurisdictional dispute in relation to a maintenance case lasted six years with all the consequent costs and associated stress. No doubt, family lawyers will reflect upon that. 